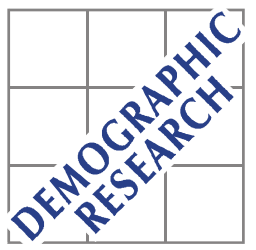

Demographic Research a free, expedited, online journal

of peer-reviewed research and commentary in the population sciences published by the Max Planck Institute for Demographic Research

Konrad-Zuse Str. 1, D-18057 Rostock · GERMANY

www.demographic-research.org

DEMOGRAPHIC RESEARCH

VOLUME 15, ARTICLE 10, PAGES 311-328

PUBLISHED 31 OCTOBER 2006

http://www.demographic-research.org/Volumes/Vol15/10/

DOI: 10.4054/DemRes.2006.15.10

Reflexion

\title{
A gender perspective on preferences for marriage among cohabitating couples
}

\section{Anne Reneflot}

\section{(C) 2006 Reneflot}

This open-access work is published under the terms of the Creative Commons Attribution NonCommercial License 2.0 Germany, which permits use, reproduction \& distribution in any medium for non-commercial purposes, provided the original author(s) and source are given credit.

See http:// creativecommons.org/licenses/by-nc/2.0/de/ 


\section{Table of Contents}

$\begin{array}{lll}1 & \text { Introduction } & 312\end{array}$

2 Theory 313

2.1 Quality-of-the-current-relationship arguments 313

$2.2 \quad$ Anticipated-change-in-quality-when-formalised arguments $\quad 315$

2.3 Wedding-burden arguments 316

2.4 Direct-normative-pressure arguments 316

3 Data 317

$4 \quad$ Results and discussion $\quad 317$

$\begin{array}{lll}4.1 & \text { Marriage intentions } & 318\end{array}$

4.2 Motives for hesitating to marry 318

$\begin{array}{lll}\text { 4.2.1 Reasons related to quality of the current relationship concerns } & 319\end{array}$

4.2.2 Reasons related to the anticipated changes in the quality of 321

4.2.3 Reasons related to the wedding 322

$\begin{array}{lll}\text { 4.2.4 Reasons related to a normative pressure } & 322\end{array}$

5 Conclusion 323

6 Acknowledgements 324

$\begin{array}{ll}\text { References } & 325\end{array}$ 


\title{
A gender perspective on preferences for marriage among cohabitating couples
}

\author{
Anne Reneflot ${ }^{1}$
}

\begin{abstract}
This paper addresses the sex differences in cohabiters' marriage preferences, which have received very little attention in the family literature. According to Norwegian survey data from 1996, cohabiting men are more hesitant to marry than cohabiting women. For example, childless male cohabiters are more worried than their female partner that another lifestyle will be expected after a marriage, and they voice more doubt about the value of the relationship. This could mean that the men generally are more individualistically oriented and therefore more attracted to single life than the women. In-depth interviews support this, and also suggest that men are less willing to yield to a normative pressure to marry. On the other hand, women were more concerned with the costs of the wedding.
\end{abstract}

${ }^{1}$ Research Fellow, Lillehammer University College, 2626 Lillehammer, Norway. Fax: +4761260750.

Telephone: +4797585110. E-mail: anne.reneflot@hil.no. 


\section{Introduction}

Many western countries have seen a surge in consensual unions over the last few decades, hand in hand with a postponement of marriage and an increasing proportion that never marry (Blom et al 1993, Bumpass et al 1991, Kiernan 1996). Informal cohabitation is especially widespread in the Nordic countries, where about half of all births occur among unmarried, and mostly cohabiting mothers (Noack 1996).

The objective of this paper is to contribute to the understanding of the factors behind the transition from consensual unions to marriage, employing a gender perspective. Just as the male and female partners may have different childbearing desires, as discussed in recent fertility studies (Thomson et al 1990, Thomson 1997, Thomson and Hoem 1998), opinions may differ on the value of marriage. A marriage will only be formed if both partners consider it an advantage, of course, but the man and the woman do not necessarily draw the same advantages from marriage, and the total advantage may not be equally strong.

Within family research there is already a vast amount of literature on how various socioeconomic characteristics of the partners influence cohabiters' marriage rate (Duvander 1999, Kravdal 1999, Manning and Smock 1995, Oppenheimer 2003, Sassler and McNally 2003). Furthermore, general theories about men and women's economic and non-economic gains from marriage have been developed, and should have some relevance to those who already cohabit (Kravdal 1999). For example, Becker (1991) has pointed to the advantage of specialisation between husband and wife, while Oppenheimer $(1988,1994)$ has emphasised that both partners may derive benefits from the pooling of resources. Other studies have addressed the changing gender roles and the persistent gendered division of labour among married couples (Hochschild 1989, Beck and Beck-Gernsheim 1995, Beck-Gernsheim 2002, Kvande and Brandt 2003). Bernard's (1972) work may be placed within the latter research tradition. She argued that men were the most reluctant to marry, fearing the loss of independence, but nevertheless drew greater advantages from marriage than women. However, we know very little about what men and women who already cohabit actually expect to achieve by transforming their union into a marriage, or their reasons for preferring to remain cohabiters. Only a few authors have addressed this issue (South 1992, Kravdal 1997, McGinnis 2003, Manning and Smock 2005), and with no explicit focus on gender differences.

In this study we first discuss some reasons why cohabiting men and women might have different motives for marrying or for preferring not to marry, using a theoretical framework suggested by Kravdal (1999). In a second step, we check whether such differences show up in Norwegian survey data from 1996, and whether there are also, on the whole, gender differences in the enthusiasm for marriage according to these data. 
Throughout the analysis a distinction is made between cohabiters with and without children. Quotations from in-depth interviews with four cohabiting couples are included in order to underpin the plausibility of some of our arguments and to shed some light on issues not covered by the survey.

\section{Theory}

Kravdal's (1999) framework is based on economic-demographic search theory for marriage (Ermisch 1991), but explicitly includes social norms. The main premise is that cohabiters, from time to time, make a decision on whether to marry soon or continue cohabitation. The framework delineates four types of arguments that are likely to be crucial in the decision-making. These are now reviewed successively, and possible differences between men and women, with or without children, are discussed for each of them.

\subsection{Quality-of-the-current-relationship arguments}

The quality of life when living with the current partner compared to the quality of life associated with being single or in more or less plausible alternative relationships is likely to be of key importance in the decision-making. Cohabitants tend to prefer cohabitation to marriage if they expect to find a better partner without too high search costs, or if they suspect they may be better off alone after a while (which is particularly likely if the current quality of the relationship is low). This hinges, of course, on the assumption that the formalities of marriage make it more difficult to end. Apart from the practical barriers, some people might not wish to break the promises they have given in public.

There are economic as well as non-economic gains from a relationship (i.e. from being a couple rather than single). For example, Becker (1991) assumes that a major benefit of marriage is the husband's specialisation in market activities and the wife's specialisation in non-market roles. The advantage of marriage may be different for the two partners, but both have something to gain (after internal negotiation of the total benefit). Oppenheimer $(1988,1994)$ has challenged this model, and argued that a collaborative or pooling-of-resource model is more in line with the new gender roles. Her idea is that both contributes economically and benefit through economy of scale (if not through being married to a richer person (relevant for only one of them)). The prediction from the latter model, given our basic idea, would be that economic 
resources would make both male and female cohabitants relatively confident about the relationship and therefore less hesitant to marry.

The non-economic gains from a relationship refer to the emotional aspect like love and intimacy (openness, sharing of thoughts and the expression of feelings). Some researchers have argued that these rewards now count more heavily than ever compared to the economic rewards, and that they have come to constitute the main fundament of a relationship (see for example Giddens (1992), who refers to unions based entirely on emotional rewards as "pure relationships", and Beck and Beck-Gernsheim (1995)). Men and women may have different views about this type of benefit. In particular, Giddens (1992) has suggested that women may appreciate the emotional closeness and exclusivity more than their male partners. According to, for example, Bernard (1972), men are more individualistically oriented and value other non-economic rewards of marriage more highly.

For men and women alike, the presence of children should increase the value of their relationship compared to the alternatives, although for somewhat different reasons. The alternatives for a woman are to live alone, typically with the main responsibility for the child, or to form a new relationship and take the child with her. Both outcomes can be problematic. Single parents are particularly likely to be exposed to economic strain, and in a new relationship there may be conflicts because the mother and her partner may have different interests in the well-being of her child (Hofferth and Anderson 2003). For a man, a disruption of the current relationship usually means that he loses the daily contact with his child. (This situation is even more pronounced in consensual unions since cohabiting fathers have poorer legal rights; see below).

This line of argument wouldn't predict any advantage from marriage. While there would usually be nothing to gain by "tying oneself to the mast" (according to these "quality of the current relationship" arguments, as opposed to the "anticipated change in quality due to formal status" arguments dealt with below), one may in certain situations want to restrict the partner's freedom. If one partner is very satisfied with the relationship and considers the associated quality close to what is realistically achievable he or she might consider it a good strategy to form a stronger bond in order to make it more difficult for the partner to leave. If the partner already is less satisfied, and gradually considers single life to be more attractive, the more satisfied person would be able to keep the union intact by "giving away" some of his or her own "quality" (i.e. internal redistribution of the total gains, as Becker would have phrased it). If the partner eventually becomes so dissatisfied that despite the other giving up everything and being left with just enough advantages to prefer to remain in the union, special barriers to disruptions might not necessarily benefit either of them. However, it is possible that a formal marriage to a greater extent than cohabitation signals to others that they should "keep away", and that one who is married also considers it less acceptable to engage in 
search-like behaviour. If that is the case, a person may want to marry to reduce the chance that a very attractive mate finds an alternative partner.

\subsection{Anticipated-change-in-quality-when-formalised arguments}

Another key factor in the theoretical framework is that the quality of a marriage may be expected to be different from that of a consensual union with the same partner. If a cohabiting couple think that they would be happier together if they marry, they would be more inclined to marry. Otherwise, they would be more inclined to remain cohabiters.

A formal marriage may increase the quality of the relationship because it provides the partners with a stronger feeling of security and commitment. This may be pleasurable in itself, and also lead people to make a greater investment in the relationship. It is possible that women make more relation-specific investments than men, for example in building up the emotional closeness, and that they are less prepared to do this in a more weakly committed relationship, which both partners would suffer from.

In contrast to a consensual union, the economic conditions and the parent-child relationship are legally regulated in a marriage. For example, by marrying, a woman can ensure her right to maintenance during the period when she has small children and therefore a low income. Marriage also offers a stronger legal protection of the fatherchild relationship. Should a break-up take place, the father will be in a stronger position if he is married (Jensen 1996, Jensen and Clausen 2000).

In addition to being institutionalised by law, marriage is also to some extent institutionalised by tradition (Duvander 1999). Married couples may be subjected to stronger expectations regarding lifestyle than cohabiting couples. For example, married couples might be expected to lead a more collectivistic lifestyle by having more mutual friends, spending more time together, and developing more common traits and interests. Cohabiting couples, on the other hand, may experience more freedom to pursue an individualistic lifestyle. Especially if men have a more individualistic orientation, as suggested above, they may fear that marriage will restrain their life too much and represent a threat to their independence. Married couples could also be subjected to more traditional gender roles. Women in particular may have reservations about marriage for this reason. It has been argued that women are more oriented towards gender equality and more democratic family ideals than men (Beck-Gernsheim 2002, Brandt and Kvande 2003). Today, young women invest in education with the intention of combining work and family life. If marriage is considered an obstacle to this project, young women may prefer cohabitation. Men, on the other hand, may experience a less 
clearly defined provider role in cohabitation than marriage (i.e. less pressure to share income with the female partner), and for this reason they may find it more economically profitable to cohabit. For example, a study by Manning and Smock (2005) found that the male provider role is stronger associated with marriage than cohabitation. Finally, parenthood may to a larger extent be expected for married couples. Marriage was previously associated with starting a family, and despite the high out-of-wedlock fertility in many rich countries, marriage for couples without children may still be taken as a signal to start a family. Young cohabitants who do not plan to have children yet may therefore prefer cohabitation to marriage.

\subsection{Wedding-burden arguments}

A third main factor in the decision to marry or not is that the entry into marriage may be considered to have some immediate and obvious time and money costs if a large wedding party is wanted or expected. The importance of this factor depends in part on whether the parents or the couples themselves finance the wedding.

Organising this important family event has normally been a woman's domain, so the female partner may well be the one who is most conscious of the time and money costs associated with a large wedding party. On the other hand, women may also attach more positive feelings towards a wedding than men do.

\subsection{Direct-normative-pressure arguments}

A fourth factor of relevance in the decision-making is the normative pressure with respect to the choice of union type. Despite the wide acceptance of cohabitation, cohabiters may still experience certain normative sanctions because they are considering challenging traditional moral codes. Close friends and family members would be the most likely to exert such pressure. In support of this (although other mechanisms may also be involved), some studies have shown that parents' views on marriage have a significant impact on their children's preferences and behaviour (Axinn and Thornton 1992).

Cohabiting parents may be subjected to a stronger normative pressure towards marriage than couples without children. In line with the argument that men hold more individualistic attitudes, they may resist such pressure more strongly than women, and it is also possible that others even make less effort to push them. 


\section{Data}

Data from Statistics Norway Omnibus Surveys of May and October 1996 are used for a simple description of sex differences in the attitude to marriage. The surveys were based on a national probability sample of 617 cohabiters that included both sexes. The non-response rates were 30 and 32 per cent in the May and October surveys, respectively (Teigum 1996). All ages between 16 and 79 were represented in the survey, but only the data for cohabiting men and women under the age of 45 previously unmarried were included in the analysis. The survey included questions to cohabiters about their marriage and childbearing plans, and if relevant, their reasons for hesitating to marry. Presumably, cohabiters have several more or less easily articulated reasons for hesitating to marry. In the Omnibus survey, they were asked to agree or disagree with twelve such reasons, which were developed from the first three of the four arguments in the theoretical framework.

As a supplement, we performed in-depth interviews with four cohabiting couples aged 25-50, who were recruited through friends and relatives. Each couple has lived together for more than two years and had at least one child together. None of the couples had immediate plans to marry (within the next year). All informants lived in suburban areas and were employed, but their level of education differed. The male and female partners were interviewed separately, with the help of a semi-structured interview guide.

One purpose of collecting qualitative data was to get some ideas about the relevance of the Direct-normative-pressure argument that were not addressed in the Omnibus survey. Furthermore, these interviews plunged deeper into the cohabitants' views on the differences between marriage and cohabitation (i.e. the Anticipatedchange-in-quality-when-formalised arguments). The cohabiters were asked how they organised their economy, their division of labour, whether this organisation could be an incentive to favour cohabitation instead of marriage for one of the partners, and their perception of various legal formalities. Some ideas related to the other two main arguments in the theoretical framework were also addressed.

\section{Results and discussion}

Two questions in the Omnibus survey shed light on the sex differences in cohabitants' overall interest in marriage. One is about the couple's marriage plans; the other is about whether the male or female partner is the one most reluctant to marry, as seen from both sides. 


\subsection{Marriage intentions}

We decided to leave out the question about the couple's marriage plans, because reported marriage plans may be an unreliable measure of individual attitudes towards marriage. They are made by the couple together, and it is not obvious whose attitudes the question actually is tapping. Presumably, the question about whether the man or the woman is the one most hesitant to marry provides more valuable information.

In table 1 below we report the proportions of who is the one most hesitant to marry among cohabiting partners. A majority, 7 out of 10 , answered that they were equally hesitant to marry as their partner. Among the remainder, there were far more who said the male partner was most hesitant than those who said that the female partner showed most reluctance. This perception of excess male hesitation is shared by male and female respondents. The pattern is the same for cohabitants with and without children.

Table 1: Percentage of the one most hesitant to marry among cohabiting partners ${ }^{\mathrm{a}}$

\begin{tabular}{|c|c|c|c|c|}
\hline \multirow[b]{2}{*}{ Who hesitate the most to marry } & \multicolumn{2}{|c|}{ No child together ${ }^{b}$} & \multicolumn{2}{|c|}{ Child together $^{b}$} \\
\hline & Women & Men & Women & Men \\
\hline We are equally hesitant to marry & 73 & 69 & 75 & 65 \\
\hline I hesitate the most to marry & 10 & 26 & 10 & 29 \\
\hline My partner hesitates the most to marry & 15 & 2 & 15 & 4 \\
\hline Non-response & 2 & 3 & 0 & 2 \\
\hline Number of men and women & & & & \\
\hline$N=429$ & 112 & 104 & 111 & 102 \\
\hline
\end{tabular}

${ }^{a}$ Only cohabitants with no plans to marry within the first year were asked whether the man or the woman is the one most hesitant to marry.

${ }^{b}$ Chi-square test has been applied and the gender differences in the tables is significant at the 1 percent level in both the "no child together" group and the "child together" group.

\subsection{Motives for hesitating to marry}

We now try to find reasons for men's stronger hesitation to marry, by looking at the respondents' answers to the question about possible motives for not wanting to marry. Table 2, which are based on a pooled May and October sample, shows the results. 
Table 2: $\quad$ Percentage of cohabiters agreeing (fully or partly) to various suggested reasons for hesitating to marry

\begin{tabular}{lcc|cc}
\hline & \multicolumn{2}{c|}{ No child together } & \multicolumn{2}{c}{ Child together $^{\mathrm{a}}$} \\
\cline { 2 - 5 } & Women & Men & Women & Men \\
\hline Reasons related to quality concerns & 30 & 31 & 6 & 9 \\
We are too young to consider marriage & 40 & 43 & 14 & 9 \\
$\begin{array}{l}\text { The relationship is too new to consider marriage } \\
\text { We are not sure we go well together }\end{array}$ & 21 & 26 & 13 & 9 \\
$\begin{array}{l}\text { As married, you cannot as easily dissolve the } \\
\text { relationship }\end{array}$ & 73 & 80 & 66 & 63 \\
$\begin{array}{l}\text { Reasons related to the possible changes in the } \\
\text { quality of the relationship when it is formalised }\end{array}$ & & & & \\
$\begin{array}{l}\text { We do not have the material standards we should } \\
\text { have as married }\end{array}$ & 21 & 22 & 12 & 10 \\
$\begin{array}{l}\text { One tends to adopt more traditional sex roles in } \\
\text { marriage }\end{array}$ & 19 & $29^{*}$ & 23 & 10 \\
$\begin{array}{l}\text { The feeling of being in love will be weakened } \\
\text { Married couples are subject to stronger }\end{array}$ & 16 & 18 & 12 & $17^{* *}$ \\
$\begin{array}{l}\text { expectations regarding lifestyle } \\
\text { Being married is not economically advantageous }\end{array}$ & 21 & $29^{*}$ & 20 & 16 \\
$\begin{array}{l}\text { Reasons related to the wedding } \\
\text { A wedding entails much work (only October) }\end{array}$ & 49 & $36^{*}$ & 58 & 63 \\
$\begin{array}{l}\text { A wedding is expensive (only October) } \\
\text { A wedding entails much work and is expensive }\end{array}$ & 66 & $50^{\star *}$ & 74 & 67 \\
$\begin{array}{l}\text { (Only May) } \\
\text { Number of men and women }\end{array}$ & 67 & $45^{*}$ & 83 & $53^{* *}$ \\
N=429 & 112 & 104 & 111 & 102 \\
\hline
\end{tabular}

${ }^{a}$ Chi-square test has been applied to the original to-ways tables (not shown) and the significant gender differences in the "no child together" group and the "child together" group is reported.

*** significant at 1 percent level; ${ }^{* *}$ significant at 5 percent level; * significant at 10 percent level.

\subsubsection{Reasons related to quality of the current relationship concerns}

The first three questions deal with the cohabiters' perception of the existing relationship, although without capturing very well the relative-quality arguments that are particularly important according to our framework. The third question is most relevant, and provides some information about the respondents' doubt about the quality of the relationship. A positive answer to the fourth question confirms the premise of the quality-of-relationship argument, namely that a consensual union is perceived to be easier to dissolve. Apart from that, however, it is not easy to interpret a "yes". One 
might suspect that a cohabitant would not report this reason for not marrying unless he or she also has some concerns about the quality of the relationship, or at least is very conscious about the possibility that it may turn sour.

As expected, only a small minority of cohabiting parents hesitate to marry out of more explicit quality concerns about the existing relationship, as judged from the answers to the first three questions. (Provided for the most part that a child is wanted, having a child is associated with a satisfaction with the quality of the existing relationship.) However, such reasons are reported by about one third of the non-parents. Generally, a much higher proportion hesitate to marry for fear of making dissolution harder, which is a more indirect signal of quality concerns, and the same differences between cohabitants with and without children are seen here.

In the non-parent group, men are slightly more concerned about the quality of the relationship than women, according to these four questions. This may partly reflect men's possibly more individualistic attitude. Among the parents, actually the women seem to be the most concerned about the quality. The quality of the union compared to the alternatives tends to be high for men because they often lose daily contact with the child after a disruption. For women, there is a risk of having the responsibility for the child alone or with a new partner, but they may consider that less of a problem.

The underlying ideal so far is that, when there is concern about the quality of the relationship, for reasons such as mentioned here, it might be particularly important to avoid a stronger bond. As explained earlier, committing oneself strongly can never be a definite advantage. However, one may gain from making it more difficult for the partner to leave. The in-depth interviews showed evidence of this line of reasoning. Two of the women said that they would prefer to marry because that would make the partner more committed to the relationship, and they would have felt this even more strongly if it were not for their common child. One of the women put it this way:

If we hadn't had children I would have thought more about securing myself by getting married, like a kind of bond. But I feel that that bond is there anyway because of the kids, because they make it so incredibly serious.

Although it might be considered particularly important to keep the man in the union in that case, their idea was apparently that he wouldn't leave anyway when he had become a father. 


\subsubsection{Reasons related to the anticipated changes in the quality of the relationship when formalised}

Several respondents in the Omnibus Survey report that they hesitate to marry because that would make the relationship less satisfactory. The reasons were, for example, that a higher material standard is expected in marriage, as well as more traditional sex roles, or that the feeling of love will be weakened. On the whole, this type of argument is somewhat more common among the childless than among those with children.

Among the non-parents, men seem to be more worried than women that life in marriage will be less satisfactory than continued cohabitation. For example, almost one third of the men fear that a marriage will be economically disadvantageous. This may reflect the generally more individualistic attitude among men mentioned earlier, or that men's traditional role is that of provider and that they fear this will enforce them to contribute more economically. In the parent group, the differences between men and women are small and again in the opposite direction. For example, more women than men hesitate to marry because they fear that married couples are subjected to stronger expectations regarding lifestyle. Women may suspect that in a marriage they would be expected to pick up more traditional gender roles, and that this would make it more difficult for them to combine care and work. For fathers, there is an additional advantage of marriage that is not picked up by any of the Omnibus questions, as also mentioned earlier: If a break-up takes place, it might be easier to stay in contact with the child if the couple are married.

The in-depth interviews provided further support for the ideal that people expect the value of marriage to be different from that of a consensual union with the same partner. Men's possible fear of a more traditional provider role, which was just referred to, was confirmed. Some informants felt that, as cohabiters, they could divide the household expenses equally and keep what was left of their income to themselves, while in marriage they would be expected to pool their incomes. Thus, a change from cohabitation to marriage may be expected to be a disadvantage, especially to men. In periods where the women worked part-time because of childcare, three out of four male informants functioned as the main provider, as this woman reported:

Now, after we had the children, we've got much more in common, because I earn less now so I depend on some money from him. Before, I was more preoccupied with providing for myself, but I've realised that it's no longer possible.

However, the interviews revealed that the provider role was less clear-cut and an object of more negotiation than one would expect in a marriage. 


\subsubsection{Reasons related to the wedding}

Not surprisingly, cohabitants who are parents are particularly inclined to report that they hesitate to marry because of the cost and work involved in a wedding. As parents, they may be particularly pressed for time, and they may also be under more economic strain. Besides, cohabiters with children may suspect that their parents are less willing to contribute financially, because the couple is considered as already established as a family. On the other hand, it is also possible that the parents would be especially willing to support in this situation because they might see a child as making a formal marriage more valuable.

Women are the most hesitant to marry because of the expense and work related to the wedding. That is the case both among the non-parents and the parents, although the sex difference is less pronounced in the latter. The fact that women attach more weight to the wedding argument than men does not necessarily mean that they appreciate the ceremony and the festivity less. In fact women might appreciate a wedding more and therefore want to put more work and money into it (Manning and Smock 2005). At least, our in-depth interviews revealed very positive attitudes among the women to being a bride, and to gathering family and friends in a big wedding party, like this woman:

It can be the sort of feeling I get in church, when I see friends get married. Because I think it's so romantic and sweet and so on, and I think, "I want to get married as well."

Given this, it may well be that a woman has a more realistic view about how much it takes - and perhaps for her in particular - to give such a party.

\subsubsection{Reasons related to a normative pressure}

The Omnibus did not contain information about reasons related to the normative pressure towards marriage. However, our impression from the in-depth interviews was that this pressure indeed was a reality, although it was rather mild, and largely restricted to the period after the birth of the first child. Only one informant reported a strong pressure that also included economic sanctions.

It was especially the women who reported both that they were exposed to some mild persuasion to marry, and that they were uncomfortable with it. The men, on the other hand, voiced a very strong resistance against being persuaded into a marriage, like this man: 
I notice that my brothers and sisters are getting married one by one and I see the photos on the wall at my parents' house. In a way I get the hint in the open space left there....then I think "what the hell!" as I'm really obstinate about things like that.....can't I have a first-class family without all that glitter and finery?

This also is in line with the assumption that men have more individualistic attitudes. The same finding is reported in another Norwegian study of cohabiters (Syltevik 2000).

\section{Conclusion}

We have learned that cohabiting men are more hesitant than women to formalise the relationship. This pattern is seen both among cohabitants with children and those who are childless, but the sex differences in the reasons for hesitating to marry differ somewhat between the two groups.

Among the childless, the men seem, for example, to fear that marriage will push them into more of a provider role. There are also indications that they have particularly strong doubts about the value of the relationship, perhaps because of a more individualistic attitude. Furthermore, they are less likely to yield to any normative pressure towards marriage. Their female partners, on the other hand, are more concerned about the wedding expenses.

Among couples with children, women actually agreed more than men with all the possible reasons for hesitating to marry that were suggested to the respondents in the Omnibus survey. With respect to the first two types of arguments, this sex pattern reflects that a relationship is generally more important to a man when he has a child and that his position as a father may be even weaker after a disruption of a consensual union than after a divorce. When cohabiting fathers nevertheless are more hesitant to marry than cohabiting mothers, on the whole, it can be a result of their stronger resistance to normative pressure also at this stage of their life. Alternatively, there may be differences in the degree of agreement with the different arguments that we cannot pick up with the Omnibus data. Although more mothers than fathers answer in the affirmative, it may well be that those fathers who say "yes" hold this opinion more strongly than the women who give this answer.

Anyway, this simple analysis has indicated that there are indeed sex differences in cohabitants' marriage preferences and in their motives for wanting or not wanting to marry. These differences deserve further exploration with richer data. A better understanding of the transition from consensual union to marriage will help us adapt 
Reneflot: A gender perspective on preferences for marriage among cohabitating couples

society to the new family behaviour and be an important underpinning for policies aimed at changing that behaviour, should such policies ever be desired.

\section{Acknowledgements}

The author wishes to thank three anonymous reviewers and Øystein Kravdal for very helpful comments. 


\section{References}

Axinn, W.G., and Thornthon, A. (1993). "Mothers, children, and cohabitation: The intergenerational effect of attitudes and behaviour." American Sociological review, 58 (2): 233-46.

Beck, U., and Beck-Gernsheim, E. (1995). The normal chaos of love. Cambridge Polity Press.

Becker, G. (1991). A treatise on the family. Cambridge: Harvard University Press.

Beck-Gernsheim, E. (2002). From 'living for others' to 'a life of one's own':

Individualization and women. In Beck, U., and Beck-Gernsheim, E. Individualization: institutionalized individualism and its social and political consequences. Londong:Sage.: 54-85.

Bernard, J. (1972). The future of marriage. New York: Bantam/World Publishing Company.

Blom, S., Noack, T., and Østby, L. (1993). Bedre sent enn aldri. SØS. Statistics Norway, Oslo-Kongsvinger. [Better late than never]

Brandt, B., and Kvande, E. (2003). Fleksible fedre: maskulinitet, arbeid, velferdsstat. Oslo:Universitetsforlaget. [Flexible fathers: masculinity, work, and the welfare state]

Bumpass, L., Sweet. J.A., and Cherlin, A.J. (1991). "The role of cohabitation in declining rates of marriage." Journal of Marriage and the Family, 53 (4):91327.

Duvander, A-Z. 1999. "The transition from cohabitation to marriage: A longitudinal study of the propensity to marry in Sweden in the early 1990s." Journal of Family Issues, 20 (5):698-717.

Ermisch, J. F. (1991). Lone parenthood. Cambridge: Cambridge University Press.

Giddens, A. (1992). The transformation of intimacy. Sexuality, love and eroticism in modern societies. Polity Press. Cambridge.

Hochschild, A. (1989). The second shift. Working parents and the revolution at home. London:Piatkus Publisher.

Hofferth, S. L., Anderson, K.G. (2003). "Are all dads equal? Biology versus marriage as a basis for paternal investment." Journal of Marriage and the Family, 65 (1):213-32. 
Jensen, A. (1996). Hva skjer med barns familier?, in Moxnes,K., and Brandt,B. (eds.), Familie for Tiden. Oslo: Tano-Aschehoug: 30-50. [What's happening to children's families?]

Jensen, A., and Clausen, S. E. (2000). Barndom - forvandling uten forhandling? Samboerskap, forelderskap og søskenskap. NIBR-rapport nr 6. [Childhood transformation without negotiation? Cohabitation, parenthood and siblinghood]

Kiernan, K. E. (1996). Partnership behaviour in Europe. In Coleman, D. (ed). Recent trends and issues, in Europe's population in the 1990s. Oxford: Oxford University Press: 62-91.

Kravdal, O. (1999). "Does marriage require a stronger economic underpinning than informal cohabitation?" Population Studies, 53 (1): 63-80.

Kravdal, O. (1997). "Wanting a child without a firm commitment to the partner: Interpretations and implications of a common behaviour pattern among Norwegian cohabitants." European Journal of Population, 13 (3): 269-98.

Manning, W., and Smock, P. (1995). "Why marry? Race and the transition to marriage among cohabiters." Demography, 32 (4):509-20.

Manning, W. and Smock, P.J. 2005."Everything's there except money": how money shapes decisions to marry among cohabiters." Journal of Marriage and the Family, 67 (3):680-96.

McGinnis, S. L. (2003). "Cohabitating, dating and perceived costs of marriage: a model of marriage entry." Journal of Marriage and the Family, 65 (1): 105-16.

Noack, T. (1996): "Familieutvikling i demografisk perspektiv" in Brandt,B., and Moxnes, K (eds.) Familie for Tiden. Oslo: TANO/Aschehoug: 11-29. [A demographic perspective on family development]

Oppenheimer, V. K. (1988). "A theory of marriage timing." American Journal of Sociology, 94 (3): 563-91.

Oppenheimer, V.K. (1994). "Women's rising employment and the future of the families in industrial societies." Population and Development Review, 20 (2):293-342.

Oppenheimer, V. K. (2003). "Cohabiting and marriage during young men's career development process." Demography, 40 (2):127-49.

Sassler, S. and McNally, J. (2003). "Cohabiting couples' economic circumstances and union transition: a re-examination using multiple imputation techniques." Social Science Research 32 (4):553-78. 
South, S. J. (1992). For love or money? Sociodemographic determinants of the expected benefits from marriage. In South, S. J., and Tolnay, S.E. (Eds.), The changing American family: Sociological and demographic perspectives. Boulder, CO: Westview Press: 171-94.

Syltevik, L. J. (2000). Differensierte familieliv. Familiepraksiser i Norge på slutten av 1990-tallet. Rapport/Senter for Samfunnsforskning; 2000/2. [Differentiated family lives. Family practices in Norway at the end of the 1990's]

Teigum, H.M. (1997). SSB 97/9.

Thomson, E., McDonald, E., and Bumpass, L.L. (1990). "Fertility Desires and Fertility: Hers, His, and Theirs." Demography, 27 (4):579-88.

Thomson, E. (1997). "Couples' childbearing desires, intentions and births." Demography, 34 (3): 343-54.

Thomson, E., and Hoem, J.M. (1998). "Couples' childbearing plans and birth in Sweden." Demography, 35 (3): 315-22. 
Reneflot: A gender perspective on preferences for marriage among cohabitating couples 